\title{
Developing Cooperative Learning Model through Teaching Materials for Prospective Indonesian Teachers
}

\author{
Trinil Dwi Turistiani \\ Universitas Negeri Surabaya \\ Surabaya, Indonesia \\ trinilturistiani@unesa.ac.id
}

\author{
Prima Vidya Asteria \\ Universitas Negeri Surabaya \\ Surabaya, Indonesia \\ primaasteria@unesa.ac.id
}

\begin{abstract}
The results of observation and discussion with teachers indicate that the practice of learning cooperative model-based Indonesian language has not been optimal. One of the causes is that the available cooperative learning books are dominated in emphasis on facts and concepts. As prospective Indonesian language teachers, students desperately need instructional materials to improve their understanding of cooperative learning theory and practice in the classroom. In this study the teaching materials will be developed into effective teaching materials covering facts, concepts, principles, and skills. The purpose of this study is to describe the process of development, quality, and effectiveness of teaching materials cooperative learning model in the course of Indonesian Language and Literature Teaching and Learning Strategy. The development method used is the Fenrich development model. Research subjects S1 2014 students Prodi Education Language and Literature Indonesia. Data were collected by technique of record, validation and test, and analyzed by using counting technique and flow technique of Miles and Huberman model. The development process of teaching materials products developed is done through the planning, designing, and developing phases. Based on the score of validation result, generally the quality of teaching materials categorized well so that it is feasible to be used in learning, and the lecturer performance categorized from good up to very good.
\end{abstract}

Keywords-teaching materials; teaching and learning strategies; cooperative learning model

\section{INTRODUCTION}

Various training on teacher qualification improvement, textbook procurement, curriculum improvement, and improvement of facilities and infrastructures are efforts to overcome educational problems, including at higher education level. The Government of Indonesia through Kemendikbud and the Directorate General of Higher Education also adapt to the emergence of learning approaches that are seen as breakthroughs, such as the application of contextual approach (CTL) with various learning strategies that are based on the approach. For example, Problem Based Learning, Cooperative Learning, Inquiry-Based Learning, Project-Based Learning, Authentic Learning, and others (Nurhadi, 2004: 56). Basically, the improvement efforts lead to student-centered, learningoriented learning, to provide a challenging and fun learning experience. Furthermore, students are expected to be familiar with deep approaches and strategic approaches in learning, not just learning to remember information or learning to graduate. The latter is often referred to as a surface approach or rote learning that is still dominant among today's students (Depdiknas, 2008).

Learning is a major aspect of the educational process because the students' learning experience during learning will play a role in the formation of skills, which will then determine the quality of education. Therefore, students as prospective teachers should understand various approaches, methods or strategies are good. This understanding will be very useful when they become teachers. A good teaching and learning strategy will determine the success of learning in the classroom. Students should be equipped with various models or teaching and learning strategies so that they are ready to face learning situations that are not in accordance with the planned.

Among the many learning models, cooperative learning should be encouraged as it aims to enhance academic cooperation among students, establish positive relationships, develop confidence, and improve academic skills through group work. In other words, Cooperative Learning is a learning approach through the use of small groups of students to work together in maximizing learning conditions in achieving learning goals (Holubec, 2001 in Nurhadi, 2004: $60)$.

Cooperative learning model is not the same as the method of discussion that is often used in learning in general or conventional learning. Cooperative learning model is developed based on several approaches that are assumed to improve the process and student learning outcomes. The approach in question is active and constructivist learning. Some of these approaches are integrated to provide a model of learning that enables students to develop their potential optimally. Active learning, demonstrated by high intellectual and emotional involvement in the learning process, is not just a physical activity. Students are given the opportunity to discuss, express their opinions and ideas, explore the material being studied and interpret the results together in groups.

In the learning process the lecturer has the academic authority to determine the methods, teaching materials, and 
evaluation. For that lecturers are required to prepare the learning device and use it as well as possible. It is intended that the goal is achieved maximally and learning can take place smoothly, directed, systematic, and have positive impact for the students. One component of the learning tool is teaching materials. Teaching materials is a set of information that must be absorbed by the students through fun lectures. Students should really feel the benefits of teaching materials or materials after learning it. In general, the nature of teaching materials can be distinguished in several categories, namely facts, concepts, principles, and skills

In general, books on existing cooperative learning models only emphasize facts and concepts. Taking into account the characteristics of cooperative learning models, it is necessary to develop teaching materials that can encourage and provide opportunities for students (prospective teachers) to communicate skillfully and share information to solve problems. Thus, the research development of learning materials cooperative learning model feasible and necessary.

\section{METHOD}

This research is a type of research development. The goal is to produce products in the form of learning materials cooperative learning model in the course of Indonesian Language and Literature Teaching and Learning Strategy. The development of newfangled products Fenrich's instructional development cycle (1997) because the model was systematic and practical in accordance with the objectives of the study, namely developing teaching materials and testing the effectiveness of the teaching materials. Here's the visual.

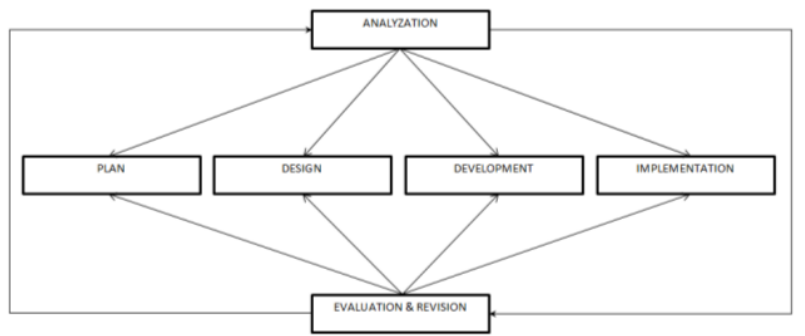

Figure Instructional Development Cycle Model (Adapted from Fenrich, 1997: 56)

Broadly speaking, at the planning stage conducted analysis, evaluation, and revision of the mapping of the subject matter of the Teaching and Learning Strategy course. At the design stage is done the preparation of features and determination of prototype teaching materials, analysis, evaluation, and revision of the features that have been prepared and prototype that has been set. At the development stage, the preparation of the materials materials as a whole based on pre-defined features and prototypes, validation, product analysis and validation results, and evaluation and revision of the product. At the implementation stage, product trial, analysis of test results, and evaluation and revision of post-test products are conducted.

Subjects in this study are students of S1 Prodi Education of Language and Indonesian Literature which program the course of Teaching and Learning Strategy. The data of this research were collected by instrument: 1) observation sheet: data collection instrument in the form of field and field notes on the process of planning, designing, and developing teaching materials, 2) validation sheet: data collection instrument in the form of contents and validator notes on the feasibility of content, presentation, language, and teaching materials, 3) test items: data collecting instruments in the form of test result score as an indicator of the effectiveness of teaching materials; 4) student response questionnaire: data collection instruments in the form of eligibility and students' impression after using the teaching materials.

The data of this study were analyzed quantitatively and qualitatively with the following techniques. Analysis of validation data, performed on each criteria relating to the component of the developed teaching material. Analysis of student test results, conducted descriptively obtained from student answers to the test questions. Analysis of student responses, performed on each criterion associated with student responses. The data in the field and field notes on the activity sheet instrument on the teaching materials development process were analyzed by Miles and Huberman (1984: 16-23). Data analysis includes data reduction, data presentation, and inferences. At the reduction, the data is organized so that it is ready to be processed. Furthermore, the data is presented in accordance with the needs of explanation. The explanation was then inferred according to the problems and needs of product development.

The teaching materials planning process begins with an analysis of student needs. Student needs analysis is done to obtain preliminary information about the need of teaching materials. This is done by asking students to answer the questionnaire needs that have been provided. The questionnaire results are used as a basis for developing teaching materials of cooperative learning model. The result of requirement analysis of learning materials obtained from the students in general is described as follows: 1) generally the students really need instructional materials cooperative learning model, b) cooperative learning model that wants to master is practical and can be applied to junior and senior high school student that is STAD, TPS, JIGSAW, and TGT, c) learning activities needed to learn competence in mastering cooperative learning model is to observe samples, discussions and presentations, and lecturers' reinforcement, d) in general the students suggest that in learning need to multiply practice activities.

At the design stage, the preparation of teaching materials is completed with revision and evaluation activities through brainstorming with colleagues to determine the components that must exist in the teaching materials model and how the composition of the substance to be comprehensive, and how to incorporate the artistic elements to be interesting. The final result of the design stage is the teaching materials that have the following specifications: 1) the product produced is a teaching material of cooperative learning model in the course of Teaching and Learning Strategy, 2) teaching materials developed using the design of learning that prioritizes the practice. The theory, example, and steps in it fully support the practice of enhancing the understanding of various cooperative 
learning models. The learning design involves observing, understanding the steps, and implementation practices; 3) broadly speaking, teaching materials have a presentation pattern that uses sequences: material explanations, sample observations, steps, and practices. In observing activities, students are asked to discuss the observations with their friends. Discussion results are used to improve the observation results. In this activity the students will gain a complete understanding of the material being studied because the lecturer will provide reinforcement. In practice, students will assess themselves through the instrument. It is expected that the presentation makes it easier for students to achieve their competence, 4) teaching materials developed in the form of books.

At the stage of development activities undertaken include activity test effectiveness draft development through expert validation and product analysis. There are two expert validators. Both validators provide an assessment of the feasibility of content components, presentation, language, and instructional materials teaching Cooperative Learning Model. In addition to providing an assessment, the validator also provides input. The inputs among which the material needs to be sharpened, the illustration drawings need to be reproduced, and case examples given should be in Indonesian language learning. In the case of sharpening of the material required the deepening of explanations by utilizing reference-reference practical and easy to understand students. In the process of development, the preparation of initial materials, revisions, and finalization based on internal review and validation. Based on the validation results compiled instructional materials Cooperative Learning Model in accordance with product analysis and expert validation results.

\section{RESULT AND DISCUSSION}

The quality of teaching materials obtained from the validation of the validators. Validation results include assessment of content feasibility, feasibility of presentation, language feasibility, and feasibility of graduation. Based on the score of the validation results, it can be stated that in general the teaching materials developed categorized well. The category suggests that teaching materials meet eligibility to be used in learning.

In the whole learning process, learning activity is the most important activity. Success in achieving learning objectives depends on the learning process being undertaken. The use of teaching materials has an important role to achieve the effectiveness of learning. Effectiveness can be seen from students' ability to master learning materials without difficulty and feel comfortable doing instruction in forming their learning experience. The effectiveness aspect of a teaching material is seen from the performance of lecturers, learning outcomes, and student responses after the learning process.

The performance of faculty in four face-to-face is measured through direct observation. The result of observation as follows: the average lecturer's performance score at the first meeting is 3.3 from the maximum score 4, the average lecturer's performance score at the second meeting is 3.6 from the maximum score of 4 , the average lecturer's performance score at the third meeting is 3.8 of the score a maximum of 4 , the average lecturer's performance score at the fourth meeting is 3.6 of the maximum score 4 . The qualitative assessment for score 1 is very less, score 2 is less, score 3 is good, and score 4 is excellent. Based on the result of observation and standard of qualitative appraisal, it can be concluded that in general the lecturer's performance in the lecture of Cooperative Learning Model by using good categorized material up to very good (average score between 3 and 4).

To know the level of mastery of the material given through the use of teaching materials Cooperative Learning Model, at the end of the learning activities held tests with the following results: 5 students got an A (85-100), 3 students got an A- (8084) 3 students got $\mathrm{B}+(75-79), 13$ students got B (70-74), 9 students got B- (65-69), 4 students got $\mathrm{C}+(60-64), 1$ student got $C$ (56-59), and 2 non-graduate students (47 and 38). The data also shows that the grade point average is 71.01 . The average is good enough. If referred to the graduation criteria, the value of 56 is the minimal score, the average or the majority of students graduate. Only $2(5 \%)$ students are under 56 (47 and 38). If referred to the completeness of learning in this course, 65 is a minimum score, 7 (17.5\%) students have not finished their study. Seven students are provided remedial material that can be studied independently, while the other 33 provided enrichment materials that can also be studied independently.

Student's responses to the learning media used were collected through questionnaires. The standard qualitative assessment for student response is SB (excellent), B (good), C (enough), $\mathrm{K}$ (less), and SK (very less). SB is equivalent to 5 which is the highest score, $\mathrm{B}$ is equivalent to 4 , and $\mathrm{C}$ is equivalent to 3 , and so on. Their responses are as follows: in the student's view the teaching materials used are very good categorized. The majority of students (43\%) rated 5, 36\% assigned a score of 4 , and $21 \%$ assigned a score of 3 .

There are several things that need to be discussed from the results of this research: a) the performance and substance of teaching materials cooperative learning model are good or very good, in accordance with the response of students have a positive contribution in improving mastery of materials, as shown in the score of test results, b) the role of lecturer as a class manager, facilitator, and a great motivator. This is evident from the existence of a significant relationship between lecturer performance and student learning outcomes. There is one thing that is underlined because even though categorized well up to very well and generally shows a tendency to rise, academically labile lecturer performance is worth asking. The data show many performance scores at a meeting lower than previous meetings, c) in terms of student responses that nullify less and less choice, there are two possible analyzes. First, they have a similar perception of the teaching materials. Second, they do not have sufficient knowledge and experience on teaching materials so it is easy to give positive value to something that is categorized as being or even below standard. 


\section{CONCLUSION}

The effectiveness of teaching materials can be seen from the performance of lecturers, student learning outcomes, and student responses. In general the performance of lecturers in learning by using teaching materials Cooperative Learning Model categorized well up to very well (score 3,3-3,8). The average of student learning outcomes is good (score 71,01). Only $2(5 \%)$ students whose grades are below the standard of graduation and $7(17.5 \%)$ students who have not finished their study. In the view of the student of teaching materials used categorized very well. The majority of students (43\%) rated 5 , $36 \%$ assigned a score of 4 , and $21 \%$ assigned a score of 3 .

\section{REFERENCES}

[1] Nurhadi, Pembelajaran Kontekstual. Malang: Penerbit Universitas Negeri Malang, 2014.

[2] Ditjen Dikti, Pembelajaran Inovatif. Jakarta: Ditjen Dikti, 2008.

[3] P. Fenrich, Practical Guidelines for Creating Instructional Multimedia Application. Fort Wort: The Dryden Press, 1997.

[4] M.B. Miles and A.M. Huberman, Qualitative Data Analysis A Sourcebook of NewMethods. London: Sage Publications, 1984 